\title{
Crystal Growth and Device Applications of Corundum-Structured Gallium Oxide
}

by

\author{
Kentaro Kaneko*, Masaya Oda**, Akio Takatsuka**, Toshimi Hitora** and Shizuo Fujita*
}

This paper reviews the evolution of corundum-structured gallium oxide $\left(\alpha-\mathrm{Ga}_{2} \mathrm{O}_{3}\right)$ semiconductors from crystal growth of single-crystalline films to potential device applications. In spite of thermodynamically metastable phase, highquality $\alpha-\mathrm{Ga}_{2} \mathrm{O}_{3}$ can be grown on sapphire substrates by the use of mist chemical vapor deposition (CVD), or mist epitaxy, allowing low-cost and high performance power devices. N-type conductivity control is achieved by Sn doping with the carrier concentration from $10^{17}$ to $10^{19} \mathrm{~cm}^{-3}$. Marked progress in performance of Schottky barrier diodes (SBDs) has been brought by the development of device structures. The most up-to-date results show on resistance and breakdown voltage of $0.1 \mathrm{~m} \Omega \cdot \mathrm{cm}^{2}$ and $531 \mathrm{~V}$ (SBD1) or $0.4 \mathrm{~m} \Omega \cdot \mathrm{cm}^{2}$ and $855 \mathrm{~V}$ (SBD2), respectively, and the record-low on resistance was demonstrated at the high breakdown voltage. These results encourage the future development of low cost and high performance power devices with $\alpha-\mathrm{Ga}_{2} \mathrm{O}_{3}$.

\section{Key words:}

Gallium oxide, Corundum, Wide bandgap, Power devices, Schottky barrier diodes, Mist deposition, Sapphire substrates, On resistance

\section{1 緒言}

$\mathrm{Ge}, \mathrm{Si}$ から始まった半導体デバイスの進展は, 一つの方 向としてバンドギャップのより大きな材料の開拓と言う 道を進んできた. $3 \mathrm{eV}$ 以上のバンドギャップを持ち, ワイ ドギャップ半導体と称される $\mathrm{SiC}$ および $\mathrm{GaN}$ は, 現在に おける一つの到達点にあり, 青色発光ダイオード(light emitting diodes; LEDs)やこれをベースとした白色 LED, 紫 外レーザダイオード(laser diodes; LDs), また低損失の電力 制御を達成するパワーデバイス等への応用により, 省エ ネルギーの社会を実現する大きな鍵を握っている.

一方, 次のターゲットと考えられている材料の一つに 酸化物半導体がある. 酸化物半導体の特徵として, 例え ば，絶縁体に近い高抵抗から透明導電膜として用いられ るほどの低抵抗を示すほか, 光・電子・磁気機能に亘る多 様な特性を示すことが挙げられる. 多くの材料は広いバ ンドギャップを持ち, 透明トランジスタ, 紫外光機能デ バイス, パワーデバイス等への忘用が期待されるととも に, 新しいスピントロニクス材料としての応用も考えら れる. 酸化物半導体のもう一つの側面は, 環境に優しい 材料という点である.酸化物は多くのものが安定で, 酸 化反応は多くの金属にとって最も生じやすい反応である. 酸化物半導体が社会で利用されることにより, 製造や廃 棄プロセスまで含めて, 安全・安心・省エネルギーをもた らしてくれる.
このようにデバイス応用の観点で多くのポテンシャル を持つ酸化物半導体であるが, 2000 年以前には半導体と なりうる高品質材料を育成するに十分な結晶成長制御が 困難であったために, 現実のデバイスを目指す研究がな かなか進まなかった, 寸なわち成長層表面での化学反応 や吸着種のマイグレーションといった過程が十分に制御 されず, 酸素空孔に代表される欠陥を生み, 半導体とし ての特性を示さなかったことが挙げられる.しかし, 禁 制帯幅 $3.4 \mathrm{eV}$ を持つ $\mathrm{ZnO}$ が紫外発光デバイスとして注目 に至ったことをきっかけに, 成長層表面の構造, 極性制 御, ステップフロー成長, ヘテロ界面での 2 次元電子ガス 形成などが可能となり, 酸化物半導体の応用に現実的な 期待が高まったわけである.

これらの成果を背景に, 最近になって酸化ガリウム $\left(\mathrm{Ga}_{2} \mathrm{O}_{3}\right)$ 半導体についての関心が高まってきた. $\mathrm{Ga}_{2} \mathrm{O}_{3}$ 半導 体は, $\mathrm{ZnO}$ より大きい約 $5 \mathrm{eV}$ に及ぶ広いバンドギャップ

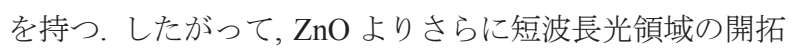
につながるとともに, 高い絶縁破壊電圧とパワーデバイ ス応用が考えられる. $\mathrm{Ga}_{2} \mathrm{O}_{3}$ の応用として, 従来から梁紫 外光検出器, 1) ガスセンサ,2),3) 電界効果トランジスタ,4) スピントロニクスデバイス 5)等を目指す研究が行われて きたが, 高品質の単結晶薄膜を実現し, 伝導性制御をも とにトランジスタ等半導体デバイスの実現につなげてゆ こうとする研究は, まだ道途上である.

$\dagger$ 原稿受理 平成28年 3月 24日 Received Mar. 24,2016

* 正 会員 京都大学 工学研究科 光・電子理工学教育研究センター $\overline{0} 615-8520$ 京都市西京区京都大学桂 Photonics and Electronics Science and Engineering Center, Kyoto University, Nishikyo-ku, Kyoto 615-8520.

** (株) FLOSFIA $\overline{\mathrm{T}} 615$-8245 京都市西京区御陵大原

FLOSFIA INC., Nishikyo-ku, Kyoto 615-8245. 
本稿では，最近の進展が著しく，パワーデバイスとし ての広い普及が期待されるコランダム構造 $\mathrm{Ga}_{2} \mathrm{O}_{3}(\alpha-$ $\left.\mathrm{Ga}_{2} \mathrm{O}_{3}\right)$ を対象に, 結晶成長とデバイス応用の進展につい てまとめ, 今後のデバイス応用への展望を示したい.

\section{$2 \mathrm{Ga}_{2} \mathrm{O}_{3}$ 半導体の結晶構造と特徵}

$\mathrm{Ga}_{2} \mathrm{O}_{3}$ 半導体は, $\alpha, \beta, \gamma, \delta, \varepsilon$ 型と表記される結晶構造を持 つ.これらのうち, 最も熱的に安定なものが単斜晶系の $\beta$ 型とされており,6) バンドギャップは 4.8-4.9 eV と報告さ れている.7) 光吸収特性等から直接遷移型のバンド構造を 持つと考えられているが,8) 間接遷移型とする計算結果も ある.9）また， $\alpha$ 型はコランダム構造をとり，準安定な相と いわれている. $\gamma$ 型はスピネル構造を持つ. 酸素空孔が生 じやすいという酸化物半導体に共通の問題から $\mathrm{n}$ 型伝導 を示すが, $\mathrm{Sn},{ }^{10)} \mathrm{Si}^{111}$ のドープにより $\mathrm{n}$ 型伝導性を制御する 試みがある。またアクセプタ形成を目指して Zn ドープを 試みた報告もある. ${ }^{12}$

$\mathrm{Ga}_{2} \mathrm{O}_{3}$ が最近になって注目されるようになったのは, バ ンドギャップが $\mathrm{SiC}$ や $\mathrm{GaN}$ より大きいために高い絶縁破 壊電界が期待でき，また高品質の $\beta-\mathrm{Ga}_{2} \mathrm{O}_{3}$ 基板が得られホ モエピタキシャル成長によるデバイスが実現できること が大きな理由である。とくに, 研究初期において, ドーピ ングやイオン注入によるキャリア密度制御が示され, ${ }^{13), 14}$ トランジスタ動作が実証 15),16)されたことが, 研究を大き く加速させた. 今後高性能のデバイスに向けた進展が大 いに期待される.

他方，われわれは，酸素という安全な元素をもつ酸化 物半導体の結晶成長について, 従来から一般的な結晶成 長法によらずとも，より安全で簡便な方法があるのでは ないかと考え，ミス卜気相成長(chemical vapor deposition; CVD)法の研究開発を進めてきた。興味ある結果は，この 技術を用いることで，サファイア基板上に準安定相の $\alpha$ $\mathrm{Ga}_{2} \mathrm{O}_{3}$ が成長することを見出したことである.これがデバ イス応用にまで進めば，安価な基板上に安価で省エネル ギーの技術で結晶成長ができ, デバイスを安価に供給で きる可能性がある.このことから， $\alpha-\mathrm{Ga}_{2} \mathrm{O}_{3}$ をべースとし たデバイスの研究開発を進めているところである.

3 コランダム構造 $\mathrm{Ga}_{2} \mathrm{O}_{3}$ 半導体の結晶成長

$3 \cdot 1$ ミスト CVD 法

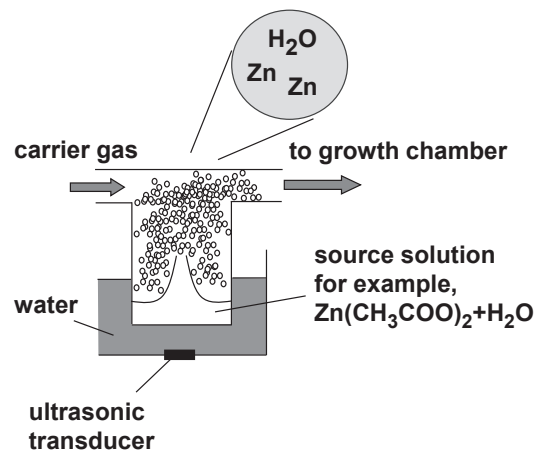

Fig. 1 Schematic illustration of mist generator.
酸化物半導体が他の半導体と大きく異なる点として, 「酸素が不純物とならない」ことが挙げられる。これは結 晶成長において大きなマージンをもたらすと言える。な ぜなら, 酸素は一般の半導体成長において最も除外に努 力を要し，また影響の大きい不純物の代表であるためで ある。あわせて, $\mathrm{AsH}_{3}, \mathrm{PH}_{3}$ のような伦険な原料を用いる 必要がない. 以上をあわせ考えると, 酸化物半導体の結 晶成長は他の半導体の結晶成長と異なったコンセプトで 行うことができるのではないかと思われる。この考えを もとにわれわれが応用を進めているのがミスト CVD法で ある。

ミスト CVD 法とは，目的とする酸化物を構成する金属 元素を含む化合物を原料とし，これを水またはアルコー ルに溶解した溶液に超音波を印加し, 得られる霧状のミ ストをキャリアガスで輸送して反応に用いる方法である. 原料としては, 金属の酢酸塩やアセチルアセトナトなど, 安全で安価なものを利用できる。ミスト発生部(原料供給 部)の概略を Fig.1 に示寸.この技術は, 従来スパッタリン グ等の真空技術を用いて成膜されていた酸化物透明電極 を，非真空技術で成膜することを目指して開発してきた ものである.14) 19)

このような方法で半導体が成長可能になれば, 成長コ ストと成長に要するエネルギーの大幅な削減をもたらし， また溶媒が強い酸化剤として働いて酸素空孔の生成を抑 える効果があると思われる. 実際, この方法で $\mathrm{ZnO}$ 単結 晶を成長したところ，良好な電気的特性とステップフロ 一成長を実現できたことから, ${ }^{20), 21)}$ 酸化物半導体の単結 晶薄膜の成長技術として大きなポテンシャルを持つと考 えられる。

\section{$3 \cdot 2$ 結晶の評価}

Fig.2 は, ミスト CVD 法により得られた $\mathrm{Ga}_{2} \mathrm{O}_{3}$ 薄膜の $\mathrm{X}$ 線回折測定結果 23)である. ここから, 得られた $\mathrm{Ga}_{2} \mathrm{O}_{3}$ 薄膜 は $\alpha$ 型であることがわかった. MBE 法では熱的に安定な $\beta$ 型が得られる 22)のに対し，これは興味ある結果である. さらに, (0006)回折に対するロッキングカーブ半值幅は

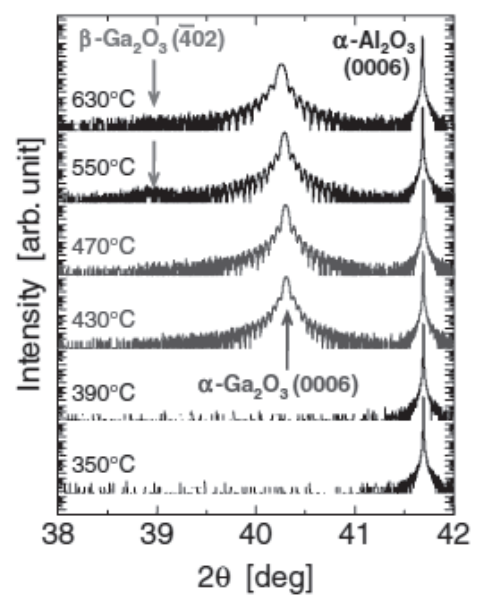

Fig. 2 XRD 2 $2 \theta / \theta$ scanning spectra of $\mathrm{Ga}_{2} \mathrm{O}_{3}$ films grown by mist CVD on sapphire substrates at various temperatures. ${ }^{23)}$ 


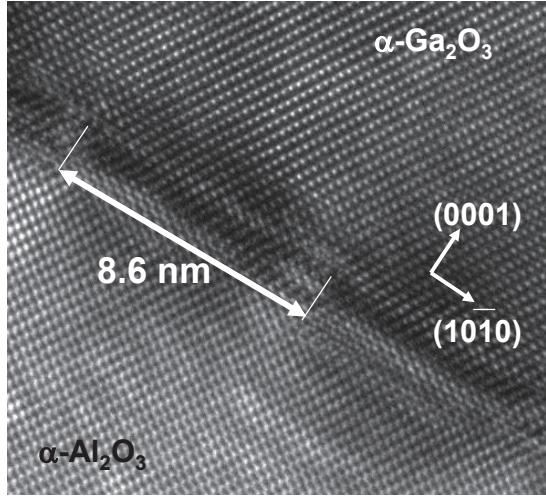

Fig. 3 Cross sectional TEM image at $\alpha$ $\mathrm{Ga}_{2} \mathrm{O}_{3} /$ sapphire $\left(\alpha-\mathrm{Al}_{2} \mathrm{O}_{3}\right)$ interface. ${ }^{24)}$

$100 \operatorname{arcsec}$ 以下と狭い. また，バンドギャップは $5.3 \mathrm{eV}$ と， $\beta-\mathrm{Ga}_{2} \mathrm{O}_{3}$ より大きい值が得られた. ${ }^{23)}$ このように, コラン ダム構造の $\alpha-\mathrm{Ga}_{2} \mathrm{O}_{3}$ が成長するのは, コランダム構造のサ ファイアを基板に用いたためと推察されるが, MBE では $\beta$ 型が主となることから，単なる基板の結晶構造への引き 込多効果ではなく，ミスト CVD 特有の低エネルギーの結 晶成長により、基板表面から薄膜への結晶格子のロッキ ング作用が、他の成長方法に比べて強く働いている事が 関係していると推察される. しかし，サファイアと $\mathrm{Ga}_{2} \mathrm{O}_{3}$ のボンド長には $4 \%$ 程度の不整合がある.にもかかわらず, 結晶性の高い薄膜が得られることは, 興味深いことであ る. 基板近傍の断面の TEM 観察の結果 24)を Fig.3 に示す. $\alpha-\mathrm{Ga}_{2} \mathrm{O}_{3}$ 成長層には欠陥があまり見られず，ロッキングカ 一ブ半值幅が小さいことを支持する。ここで, 界面の構 造に着目すると, 約 $9 \mathrm{~nm}$ を周期とするコントラストが見 られる. $\alpha-\mathrm{Ga}_{2} \mathrm{O}_{3}$ の(1010)方向(構造に平行な方向)の格子定 数が $0.43 \mathrm{~nm}$ であり, サファイアのそれは $0.41 \mathrm{~nm}$ である. これらは前者の 20 周期, サファイアの 21 周期にあたる 約 $8.6 \mathrm{~nm}$ と良い一致を示寸ことから, 約 $9 \mathrm{~nm}$ を大きな周 期とした格子整合構造を持って成長したのではないかと 思われる. ${ }^{24)}$

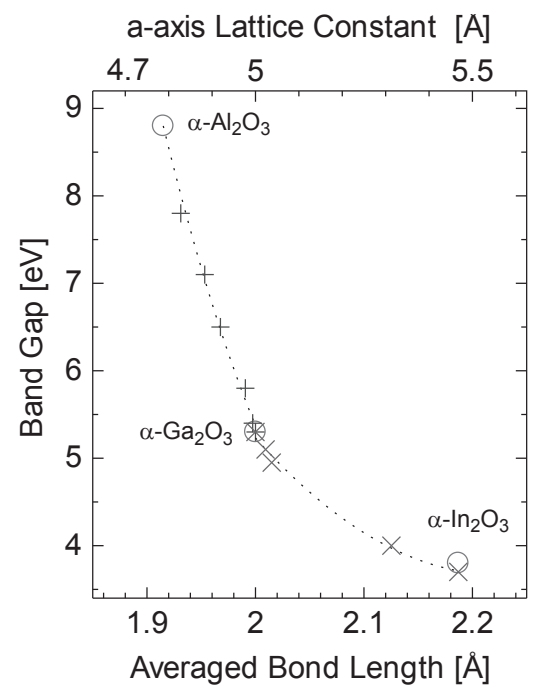

Fig. 4 Composition control of $\alpha-(\mathrm{Al}, \mathrm{Ga})_{2} \mathrm{O}_{3}$ and $\alpha-(\mathrm{In}, \mathrm{Ga})_{2} \mathrm{O}_{3}{ }^{26)}$
このように：ミスト CVD 法により $\alpha-\mathrm{Ga}_{2} \mathrm{O}_{3}$ が成長する ことは, 同じコランダム構造を持つ他の酸化物半導体と の広い組成にわたる混晶を成長可能なことを示唆する. $\beta$ 型は特殊な結晶構造で $\beta-\mathrm{Ga}_{2} \mathrm{O}_{3}$ が存在するのみであるが， $\alpha$ 型については $\alpha-\mathrm{Al}_{2} \mathrm{O}_{3}$ および $\alpha-\mathrm{In}_{2} \mathrm{O}_{3}$ が存在することが知 られている。したがって，これらの混晶すなわち In $)_{2} \mathrm{O}_{3}$ によるバンドギャップエンジニアリングおよび多 層構造による物性創成という, デバイスの基本要件を満 たすことができる.ただし, $\alpha-\mathrm{In}_{2} \mathrm{O}_{3}$ は準安定状態であるた め, その成長条件を踏まえて混晶の成長を行う必要があ る. われわれは, サファイア基板上の $\alpha-\mathrm{Fe}_{2} \mathrm{O}_{3}$ バッファ層 を用いることで $\alpha-\mathrm{In}_{2} \mathrm{O}_{3}$ の成長が可能になることを見出し た. ${ }^{25)}$ 引き続き, Fig.4 に示すように $\alpha-(\mathrm{Al}, \mathrm{Ga}, \mathrm{In})_{2} \mathrm{O}_{3}$ 混晶に

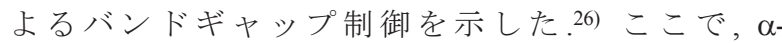
$(\mathrm{Al}, \mathrm{Ga})_{2} \mathrm{O}_{3}$ は全体の組成範囲にわたつて単一相の混晶が 得られ，ボウイングパラメータも小さいのに対し, $\alpha-(\mathrm{Ga}$, In $)_{2} \mathrm{O}_{3}$ については中間の組成領域で相分離が見られ，ボウ イングパラメータも大きい.この傾向は $\mathrm{AlGaN}$ および InGaN とそれぞれ対応するもので，金属元素の種類によ る共通の効果があるようである。また，コランダム構造 を持つ酸化物半導体としては, 半導体以外の多様な機能 を持つ遷移金属酸化物 $\left(\mathrm{Fe}_{2} \mathrm{O}_{3}, \mathrm{Cr}_{2} \mathrm{O}_{3}\right.$ など)が存在する。 $\alpha$ $\mathrm{Ga}_{2} \mathrm{O}_{3}$ とこれらの混晶化により, 新規な機能の創成が考え られる. 例として, $\alpha-\mathrm{Ga}_{2} \mathrm{O}_{3}$ と $\alpha-\mathrm{Fe}_{2} \mathrm{O}_{3}$ とを混晶化した $\alpha-$ $\left(\mathrm{Fe}_{x} \mathrm{Ga}_{1-x}\right)_{2} \mathrm{O}_{3}$ において, 室温以上での強磁性を持つ半導体 を実現し得た.27)

\section{$3 \cdot 3$ ドーピングによる電気特性制御}

$\alpha-\mathrm{Ga}_{2} \mathrm{O}_{3}$ はバンド絶縁体であり、ノンドープでは電気伝 導性を示さない. しかしながら, 2012 年に川原村等, ${ }^{28)}$ 赤 岩等 ${ }^{29)}$ が相次いで $\mathrm{Sn}$ ドープによる導電性 $\mathrm{n}$ 型 $\alpha-\mathrm{Ga}_{2} \mathrm{O}_{3}$ の 作製を報告した。特に赤岩等は, Sn を $0.4 \%$ ドープした試 料において, Hall 移動度 $2.8 \mathrm{~cm}^{2} / \mathrm{Vs}$, キャリア密度 $2.7 \times$ $10^{19} / \mathrm{cm}^{3}$ の值を得た。しかしながら, 当時のミスト CVD 装置は，ステンレス部材からの金属溶出を十分に防ぎき れておらず，また多くのシリコーン製部材を使用してい たことから，薄膜中に金属部材からの $\mathrm{Fe}$ や $\mathrm{Cr}$ イオンを

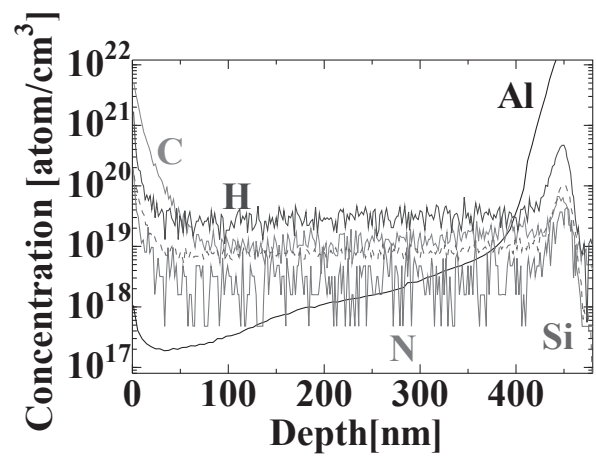

Fig. 5 Atomic densities of impurities of C, H, N, Si and $\mathrm{Al}$ in non-doped $\alpha-\mathrm{Ga}_{2} \mathrm{O}_{3}$ films measured by SIMS technique. ${ }^{29)}$ 


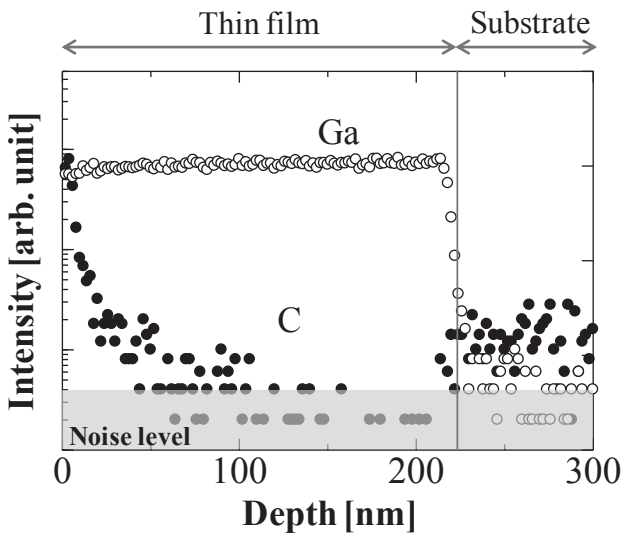

Fig. 6 SIMS spectrum of $\mathrm{C}^{12}$ and Ga elements in the $\alpha$ $\mathrm{Ga}_{2} \mathrm{O}_{3}$ thin film and sapphire substrate. ${ }^{30)}$

はじめ, C, H, N, Si が 10 $17-10^{19} / \mathrm{cm}^{3}$ 存在し(Fig.5), それぞれ 中性不純物やドナーとして作用するため, 電子走行パス を阻害し，また意図した以上のキャリアが発生するため, 電気伝導性を阻害する原因となっていた，そのため，得 られた電気特性は，半導体よりもむしろ金属の電気特 性に近い，高キャリア密度，低移動であった。

しかしながら、その後の装置改良等により，薄膜中の Fe や $\mathrm{Cr}$ 等の不純物の濃度を低減させる事に成功した. 2014 年の ROCA 株式会社 (現 (株) FLOSFIA)からの報告では, 前駆体溶液の作製条件を工夫し, Ga のハロゲン化合物を 用いることで, カーボンコンタミの劇的な低減に成功し た. Fig.6 は SIMS 測定による, $\alpha-\mathrm{Ga}_{2} \mathrm{O}_{3}$ 薄膜中における $\mathrm{Ga}$ と $\mathrm{C}^{12}$ の深さ方向濃度の測定結果 29)である. 薄膜表面では, 空気中から飛散したカーボンコンタミが確認されるが, 薄膜中においてその濃度は非常に小さく，検出限界 $\left(10^{17} / \mathrm{cm}^{3}\right)$ 未満の領域も確認できる. ${ }^{30)}$ さらに, 2015 年に赤 岩等によって Hall 移動度 $24 \mathrm{~cm}^{2} / \mathrm{Vs}$ をもつ $\alpha-\mathrm{Ga}_{2} \mathrm{O}_{3}$ 薄膜の 作製が報告されており，その電気特性は年々向上してい る. ${ }^{31)}$ (a)

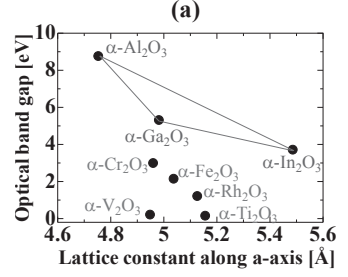

(c)
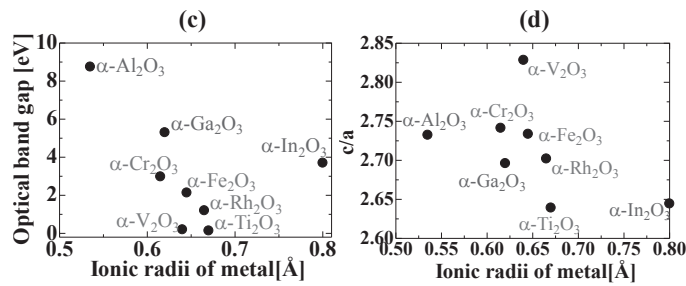

Fig. 7 Relationships between optical band-gaps with aaxis lattice constant (a), c-axis one (b), ionic radii (c). (d) is a dependence of c/a ratio of lattice constant and ionic radii. ${ }^{32}$
4 コランダム構造 $\mathrm{Ga}_{2} \mathrm{O}_{3}$ 半導体を用いたデバイス

コランダム構造酸化物のデバイス応用を考慮した場 合, $\alpha-\mathrm{Ga}_{2} \mathrm{O}_{3}$ は大変重要な役割を担う. Fig.7は 8 種類存在 するコランダム構造酸化物の光学バンドギャップと, (a) a軸長, (b) c軸長, (c) イオン半径の関係と, c/a軸比とイオ ン半径の相関を示した図である. ${ }^{32)}$ いずれの図中におい ても， $\alpha-\mathrm{Ga}_{2} \mathrm{O}_{3}$ は中央に位置し，混晶作製において $\alpha-$ $\mathrm{Ga}_{2} \mathrm{O}_{3}$ の作製がキーテクノロジーとなる事が示される。 特にデバイス作製においては，バンドギャップ值が大き く異なる $\alpha-\mathrm{In}_{2} \mathrm{O}_{3}(3.7 \mathrm{eV})$ と $\alpha-\mathrm{Al}_{2} \mathrm{O}_{3}(8.7 \mathrm{eV})$ の高品質混晶 作製は困難であり, $\alpha-\mathrm{Ga}_{2} \mathrm{O}_{3}$ を介してバンドギャップチ ユーニングする事によって，高品質な混晶の作製が可能 となり，将来的には高速電子デバイス(high electron mobility transistor; HEMT)をはじめ, へテロ構造を利用し たデバイスへの応用が期待できる. そして、 $\alpha-\mathrm{Ga}_{2} \mathrm{O}_{3}$ 単体 も, 光学バンドギャップ值が $5.3 \mathrm{eV}$ というダイヤモンド $(5.49 \mathrm{eV})$ に匹敵する大きなバンドギャップを有する魅力 的な材料であり，パワーデバイス応用をはじめ，様々な デバイスへの展開が期待される. (株) FLOSFIAからは, これまで、 $\mathrm{c}$ 面サファイア基板上に作製した高品質 $\alpha$ $\mathrm{Ga}_{2} \mathrm{O}_{3}$ 薄膜を利用したショットキーバリアダイオードが 報告されている.

\section{$4 \cdot 1$ 横型ショットキーバリアダイオード}

Fig.8 は、ミスト CVD 法により作製した横型ショット キーバリアダイオード(SBD)の構造と, その電流-電圧特 性である.Ptをショットキー電極に用いることでショット

\section{(a)}

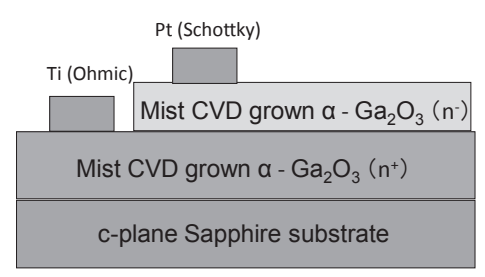

(b)

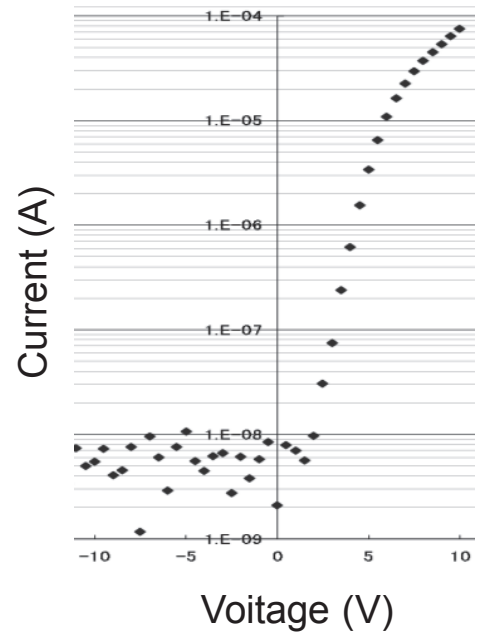

Fig. 8 Schematic image of horizontal SBD based on $\alpha-\mathrm{Ga}_{2} \mathrm{O}_{3}(\mathrm{a})$ and $\mathrm{I}-\mathrm{V}$ characteristic (b) ${ }^{33)}$. 


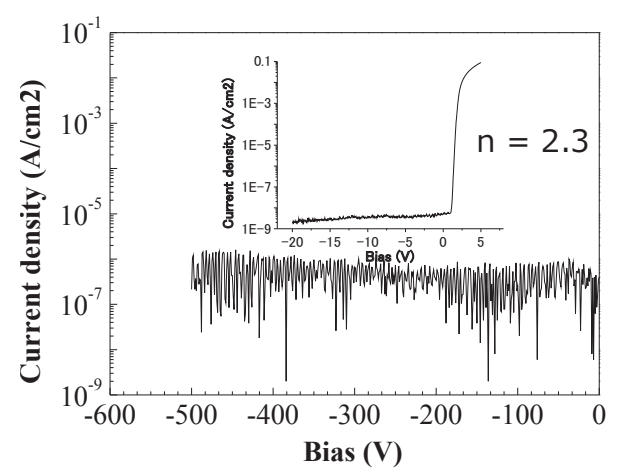

Fig. 9 Forward (inside figure) and reverse J-V characteristics of a $\alpha-\mathrm{Ga}_{2} \mathrm{O}_{3}$ SBD. ${ }^{34)}$

キー特性が確認され, 横型 SBD の作製に成功した. ${ }^{33)} し$ かしながら，その ON/OFF 值は $10^{4}$ 未満と小さく，また順 方向電流の值も $10 \mathrm{~V}$ で $100 \mu \mathrm{A}$ 未満であり, パワーデバイ ス応用を目指した SBD の特性としては十分なものではな かった。その原因として、膜中の不純物密度が高く, $\alpha$ $\mathrm{Ga}_{2} \mathrm{O}_{3}$ 薄膜の比抵抗值が高いため, 横方向の電流值が低く, また表面平坦性も十分ではなかったので，ショットキー 電極下でのリーク電流が原因で, 低い逆方向耐圧を示す 結果となった。

そこで，成長システムの改良により, $\alpha-\mathrm{Ga}_{2} \mathrm{O}_{3}$ 膜中の不 純物濃度を低減させ，また成長条件を最適化させること で，表面平坦性を向上させた薄膜を用いて SBD を作製し た. Fig.9 は，その電流-電圧特性である. ${ }^{34)}$ 逆方向-100V における漏れ電流值は $10 \mathrm{nA} / \mathrm{cm}^{2}$ 未満であり，さらに絶縁 破壊電圧も $500 \mathrm{~V}$ 以上と高い值を示した。またその障壁高 さを計算すると $1.2 \mathrm{eV}$ であった。 しかしながら，理想形数

(a)

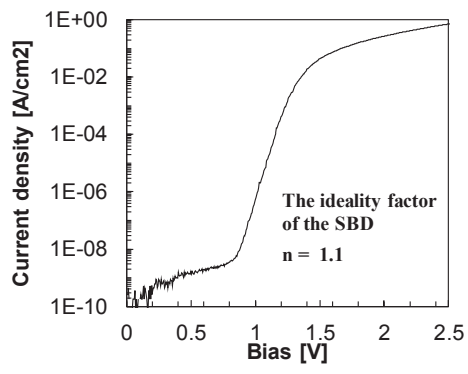

(b)

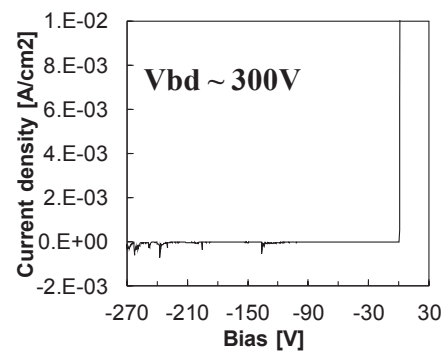

Fig. 10 Forward current density (J) versus voltage (V) characteristics of vertical SBD structure with $\alpha-\mathrm{Ga}_{2} \mathrm{O}_{3}$ (a) and reverse one (b). ${ }^{35)}$ (n) が 2.3 と大きく, コンタクト抵抗の低減を含めて, 順 方向特性を改善することが課題であった.

$4 \cdot 2$ 縦型ショットキーバリアダイオード

$\alpha-\mathrm{Ga}_{2} \mathrm{O}_{3}$ の移動度は比較的低く, 横型 SBD の作製には 現状としても課題が多い。また, サファイア基板は熱伝 導率が低く，またサファイア基板を用いる限り，横型 SBD しか作製することができない.

この問題に対し, (株) FLOSFIA では，サファイア基板か ら $\alpha-\mathrm{Ga}_{2} \mathrm{O}_{3}$ 薄膜層を剥離して, その裏面にオーミック電極 を形成することで，自立型の縦型 SBD を作製するという 考え方を実現するに至った. Fig.10 はその電流-電圧特性 である. 順方向において $n=1.1$ と大きく改善されており, SBD として理想的特性に大きく近づいた. また，逆方向 特性において, 絶縁破壊電圧は $300 \mathrm{~V}$ 近くあり, 大きな耐 圧を有している事が示された. 35

さらに最適化を進めた結果得られた SBD の電流-電圧 特性が Fig.11 である.35) これより、オン抵抗と絶縁破壊電 圧の值について, SBD1 ではそれぞれ $0.1 \mathrm{~m} \Omega \cdot \mathrm{cm}^{2}, 531 \mathrm{~V}$, SBD2 において, $0.4 \mathrm{~m} \Omega \cdot \mathrm{cm}^{2}, 855 \mathrm{~V}$ の值が得られた。ここ で得られた $0.1 \mathrm{~m} \Omega \cdot \mathrm{cm}^{2}$ というオン抵抗值は, SiC SBD と比 較して十分小さい值であり, 結晶性の向上と成長層の基 板からのはく離という相乗効果によりもたらされたもの といえる。またサファイア基板をはく離したことで, デバ イスを放熱板に直接マウントして放熱効果を高めること も可能である.

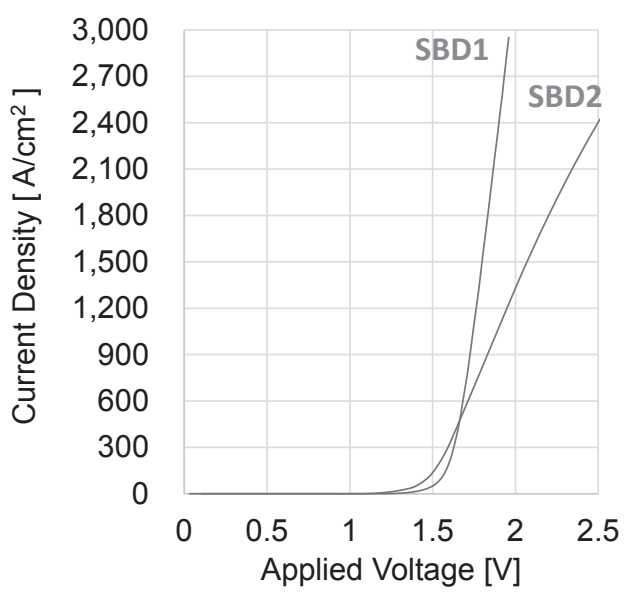

Fig. 11 Forward current density versus applied voltage characteristics of $\alpha-\mathrm{Ga}_{2} \mathrm{O}_{3}$ SBDs. ${ }^{36}$

\section{5 結 言}

ミスト CVD という安全、簡便、省エネルギーの結晶成 長技術により，サファイア基板上に高品質のコランダム 構造 $\alpha-\mathrm{Ga}_{2} \mathrm{O}_{3}$ 半導体が得られる. これを用いたデバイスの 研究開発は, 高性能なデバイスを安価に供給できるとい う意義を持ち, パワーデバイスの大いなる普及に貢献し うるものと考えられる。きわめて低いオン抵抗をもつ SBD の実証はその一例であり，今後その実用化と各種デ バイスへの展開が大いに期待される. 


\section{参 考 文 献}

1) Y. Kokubun, K. Miura, F. Endo and S. Nakagomi, "Solgel prepared $\mathrm{B}-\mathrm{Ga}_{2} \mathrm{O}_{3}$ thin films for ultraviolet photodetectors", Applied Physics Letters, Vol.90, Iss.3, 031912(1-3) (2007).

2) C.-Cheng Chen and C.-Chen Chen, "Morphology and electrical properties of pure and Ti-doped gas-sensitive $\mathrm{Ga}_{2} \mathrm{O}_{3}$ film prepared by rheotaxial growth and thermal oxidation", Journal of Materials Rersearch, Vol.19, No.4, pp.1105-1117 (2004).

3) M. Ogita, K. Higo, Y. Nakanishi and Y. Hatanaka, " $\mathrm{Ga}_{2} \mathrm{O}_{3}$ thin film for oxygen sensor at high temperature", Applied Surface Science, Vol.175-176, pp.721-725 (2001).

4) K. Matsuzaki, H. Yanagi, T. Kamiya, H. Hiramatsu, K. Nomura, M. Hirano and H. Hosono, "Field-induced current modulation in epitaxial film of deep-ultraviolet transparent oxide semiconductor $\mathrm{Ga}_{2} \mathrm{O}_{3}$ ", Applied Physics Letters, Vol.88, Iss.9, 092106(1-3) (2006).

5) H. Hayashi, R. Huang, H. Ikeno, F. Oba, S. Yoshioka, I. Tanaka and S. Sonoda, "Room temperature ferromagnetism in $\mathrm{Mn}$-doped $\gamma-\mathrm{Ga}_{2} \mathrm{O}_{3}$ with spinel structure", Applied Physics Letters, Vol.89, Iss.18, 181903(1-3) (2006).

6) P. P. Macri, S. Enzoa, G. Sberveglierib, S. Groppellib, and C. Perego, "Unknown $\mathrm{Ga}_{2} \mathrm{O}_{3}$ structural phase and related characteristics as active layers for $\mathrm{O}_{2}$ sensors", Applied Surface Science, Vol.65-66, pp.277-282 (1993).

7) H. H. Tippins, "Optical absorption and photo-

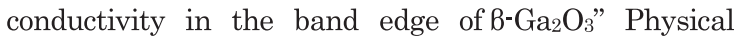
Review, Vol.140, Iss.1A, pp.A316-A319 (1965).

8) M. Orita, H. Ohta, M. Hirano, and H. Hosono "Deepultraviolet transparent conductive $6-\mathrm{Ga}_{2} \mathrm{O}_{3}$ thin films", Applied Physics Letters, Vol.77, Iss.25, pp.4166-4168 (2000).

9) K. Yamaguchi, "First principles study on electronic structure of $\mathrm{B}-\mathrm{Ga}_{2} \mathrm{O}_{3}$ ", Solid State Communications, Vol.131, Iss.12, pp.739-744 (2004).

10) N. Ueda, H. Hosono, R. Waseda and H. Kawazoe, "Synthesis and control of conductivity of ultraviolet

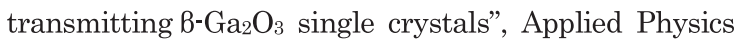
Letters, Vol.70, No.26, pp.3561-3563 (1997).

11) E. G. Villora, K. Shimamura, Y. Yoshikawa, T. Ujiie and K. Aoki, "Electrical conductivity and carrier concentration control in $8-\mathrm{Ga}_{2} \mathrm{O}_{3}$ by Si doping", Applied Physics Letters, Vol.92, No.20, 202120(1-3) (2008).

12) P.C. Chang, Z. Fan, W.Y. Tseng, A. Rajagopal and H.G. $\mathrm{Lu}$, " $\mathrm{B}-\mathrm{Ga}_{2} \mathrm{O}_{3}$ nanowires: Synthesis, characterization, and pp-channel field-effect transistors", Applied Physics Letters, Vol.87, No.22, 222102(1-3) (2005).

13) K. Sasaki, A. Kuramata, T. Masui, E. G. Víllora, K. Shimamura and S. Yamakoshi, "Device-quality B$\mathrm{Ga}_{2} \mathrm{O}_{3}$ epitaxial films fabricated by ozone molecular beam epitaxy", Applied Physics Express, Vol.5, No.3, 035502(1-3) (2012).

14) K. Sasaki, M. Higashiwaki, A. Kuramata, T. Masui and S. Yamakoshi, "Si-ion implantation doping in B$\mathrm{Ga}_{2} \mathrm{O}_{3}$ and its application to fabrication of low-resistance Ohmic contacts", Applied Physics Express, Vol.6, No.8, 086502(1-3) (2013).
15) M. Higashiwaki, K. Sasaki, A. Kuramata, T. Masui and S. Yamakoshi, Applied Physics Letters, "Gallium oxide $\left(\mathrm{Ga}_{2} \mathrm{O}_{3}\right)$ metal-semiconductor field-effect transistors on single-crystal B- $\mathrm{Ga}_{2} \mathrm{O}_{3}(010)$ substrates", Vol.100, No.1, 013504(1-3) (2012).

16) M. Higashiwaki, K. Sasaki, T. Kamimura, M. H. Wong, D. Krishnamurthy, A. Kuramata, T. Masui and S. Yamakoshi, "Depletion-mode $\mathrm{Ga}_{2} \mathrm{O}_{3}$ metal-oxidesemiconductor field-effect transistors on $\mathrm{B}_{-} \mathrm{Ga}_{2} \mathrm{O}_{3}(010)$ substrates and temperature dependence of their device characteristics", Applied Physics Letters, Vol.103, No.12, 123511(1-3) (2013).

17) T. Kawaharamura, H. Nishinaka, K. Kametani, Y. Masuda, M. Tanigaki and S. Fujita, "Fabrication and properties of $\mathrm{ZnO}$ thin films prepared by fine channel mist method", Journal of the Society of Materials Science, Japan, Vol.55, No.2, pp.153-158 (2006).

18) H. Nishinaka, T. Kawaharamura and S. Fujita, "Low" temperature growth of $\mathrm{ZnO}$ thin films by linear source utrasonic spray chemical vapor deposition", Japanese Journal of Applied Physics, Vol.46, No.10A, pp.68116813 (2007).

19) T. Kawaharamura, H. Nishinaka and S. Fujita, "The effect of fine channel \& collisional mixing on mist CVD method", Journal of the Society of Materials Science, Japan, Vol.57, No.5, pp.781-487 (2008)..

20) H. Nishinaka, Y. Kamada, N. Kameyama and S. Fujita, "Epitaxial $\mathrm{ZnO}$ thin films on a-plane sapphire substrates grown by ultrasonic spray-assisted mist chemical vapor deposition", Japanese Journal of Applied Physics, Vol.48, No.12, 121103(1-5) (2009).

21) H. Nishinaka and S. Fujita, "Step-flow growth of homoepitaxial $\mathrm{ZnO}$ thin films by ultrasonic spray assisted MOVPE", Journal of Crystal Growth, Vol.310, Iss.23, pp.5007-5010 (2008).

22) T. Oshima, T. Okuno and S. Fujita, " $\mathrm{Ga}_{2} \mathrm{O}_{3}$ thin film growth on c-plane sapphire substrates by molecular beam epitaxy for deep-ultraviolet photodetectors", Japanese Journal of Applied Physics, Vol.46, No.11, pp.7217-7220 (2007).

23) D. Shinohara and S. Fujita, "Hetero-epitaxy of corundum-structured $\alpha-\mathrm{Ga}_{2} \mathrm{O}_{3}$ thin films on $\alpha$ $\mathrm{Al}_{2} \mathrm{O}_{3}$ substrates by ultrasonic mist chemical vapor deposition", Japanese Journal of Applied Physics, Vol.47, No.9, pp.7311-7313 (2008).

24) K. Kaneko, H. Kawanowa, H. Ito and S. Fujita, "Evaluation of misfit relaxation in $\alpha-\mathrm{Ga}_{2} \mathrm{O}_{3}$ epitaxial growth on $\alpha-\mathrm{Al}_{2} \mathrm{O}_{3}$ substrate", Japanese Journal of Applied Physics, Vol.51, No.2, 020201(1-3) (2012).

25) N. Suzuki, K. Kaneko and S. Fujita, "Growth of corundum-structured $\mathrm{In}_{2} \mathrm{O}_{3}$ thin films on sapphire substrates with $\mathrm{Fe}_{2} \mathrm{O}_{3}$ buffer layers", Journal of Crystal Growth, Vol.364, Iss.2, pp.30-33 (2013).

26) S. Fujita and K. Kaneko, "Epitaxial growth of corundumstructured wide band gap III-oxide semiconductor thin films", Journal of Crystal Growth, Vol.401, pp.588-592, (2014).

27) K. Kaneko, I. Kakeya, S. Komori and S. Fujita, "Band gap and function engineering for novel functional alloy semiconductors: Bloomed as magnetic properties at 
room temperature with a-( $\mathrm{GaFe})_{2} \mathrm{O}_{3}$ ", Journal of Applied Physics, Vol.113, Iss.23, 233901(1-6) (2013).

28) T. Kawaharamura, G. T. Dang and M. Furuta, "Successful growth of conductive highly cystalline $\mathrm{Sn}^{-}$ doped $\alpha-G a 2 O 3$ thin films by fine-channel mist chemical vapor deposition" Japanese Journal of Applied Physics, Vol 51, No.4R, 040207(1-3) (2012).

29) K. Akaiwa and S. Fujita, "Electrical conductive corundum-structured $\alpha-\mathrm{Ga}_{2} \mathrm{O}_{3}$ thin films on sapphire with tin-doping grown by spray-assisted mist chemical vapor deposition" Japanese Journal of Applied Physics, Vol 51, No.7R 070203(1-3) (2012).

30) M. Oda, K. Kaneko, T. Hitora and S. Fujita, "Synthesis of $\alpha-\mathrm{Ga}_{2} \mathrm{O}_{3}$ thin films for device applications" 33th Electronic Materials Symposium, We2-4.

31) K. Akaiwa, K. Kaneko and Shizuo Fujita, "Electrical property of Sn-doped corundum-structured $\mathrm{Ga}_{2} \mathrm{O}_{3}$ thin films on sapphire substrates" 42nd International Symposium on Compound Semiconductors, Mo4PP-E.21

32) K. Kaneko, "Fabrication and physical properties of corundum-structured alloys based on gallium oxide" Doctor thesis, Kyoto Univ. (2013)

33) M. Oda and T. Hitora, "Growth of high quality $\alpha-\mathrm{Ga}_{2} \mathrm{O}_{3}$ thin films on 4-Inch sapphire wafer" Materials Reserch Conference Fall Meting 2013,

34) M.Oda, A. Takatsuka, T. Hitora, J. Kikawa, K. Kaneko and S. Fujita, " $\alpha-\mathrm{Ga}_{2} \mathrm{O}_{3}$ Schottky barrier diodes fabricated by Mist Epitaxy technique" 46th International Conference on Solid State Device and Materials N-1-5

35) M.Oda, J. Kikawa, A. Takatsuka, R. Tokuda, T. Sasaki, K. Kaneko and S. Fujita, and T. Hitora ," Vertical Schottky Barrier Diodes of $\alpha^{-} \mathrm{Ga}_{2} \mathrm{O}_{3}$ Fabricated by MIST EPITAXY®” 73rd Device Research Conference P29

36) M. Oda, R. Tokuda, H. Kambara, T. Tanikawa, T. Sasaki and T. Hitora, "Schottky barrier diodes of corundum" structured gallium oxide showing on-resistance of $0.1 \mathrm{~m} \Omega \mathrm{cm}^{-2}$ grown by MIST EPITAXY®”, Applied Physics Express, Vol.9, No.2, 021101(1-3) (2016). 